\title{
The Dangers of Self-Diagnosis and Self-Help
}

\author{
Stavroula Georgakopoulou* \\ Psychologist, University of Athens, Greece
}

Submission: March 28, 2017; Published: March 31, 2017

*Corresponding author: Stavroula Georgakopoulou, Psychologist, CBT Therapist, University of Athens, Greece, Tel: 6934650265;

Email: stavrou.geor@gmail.com

\section{Abstract}

We all have been through times where we wondered: "What is really going on with me?" Often we might feel the need to name the whole situation we are into.

As far as for our internal concerns we tend to give a psychological term like Depression, Panic attacks, obsessions etc.

\section{Introduction}

\section{Internet - Media}

Our information is now so diverse and accessible at any time that we can read or watch something that we think is very close to how we feel.

\section{Relationships}

Sometimes we can be affected by other people opinion about what is wrong with us or by other people's emotional state. We could think: "Well, I think that I have exactly the same problem as this person".

\section{Family-Relatives}

We believe that if our close cycle suffers from a mental illness we too are going to inherit this. We often don't take into consideration that Internet and Media have great advantages and disadvantages. From the one hand they offer variable information but from the other hand lots of them are noncross, indefinite and not significally proven. Yet, in many cases every symptom occurs differently in each human, for a specific reason and for a different duration. As we cannot make alone a diagnosis for a viral infection, we also cannot find successfully our psychological dysfunction and treat it ourselves. When we do feel the urge to learn what is happening to us, it is always necessary to base our concern on a diagnosis from a Mental Health expert. Our own people, even our family, most often "know" what is best for us. They worry about us, look for us and suggest us what they think will help. Definitely people who care for our mental health are trying to do the best they can.
But what if we follow Advisory services including drug treatment; given to someone else with similar symptoms to ours?

The human body interacts differently to drugs and doses. It is very important to visit a qualified Psychiatrist to approve taking or not a psychiatric drug.

\section{"Someday, I will finally get over this"}

Several of us have heard this phrase, very likely we too have been told it to ourselves. In our daily lives we are trying to forget or to improve ourselves from our psychological distress.

\section{We have to take the following warnings very seriously}

i. Our Psychological state affects seriously our functioning in different areas of life (Job, family, relationship, important activities for one person)

When things we used to do easily now we are getting easily tired of them, when we encounter difficulty completing our work and these feelings are new to us we need to pay attention to it.

Our body like our feeling endeavor to notify us first when something goes wrong. Very typically a panic attack is "alarm" that asks us to guard or to finally deal with serious issues that we have left unresolved in us. Panic attack is not accidentally connected to depression. So we need to begin to take seriously what we sense and feel, because prompt treatment is the most effective. The accumulation of psychological difficulties makes it more difficult and time consuming to cope with. 


\section{ii. Our own people tell us that they see us changed.}

There is a probability, not having realized how a psychological difficulty has been affecting us. We need to take into account such kind comments.

\section{Can I truly improve myself?}

Human is born to deal with hard and threatening situations. He can fall down and find the strength and courage to get up again. During our lifetime we receive lots of emotional experiences that we couldn't or didn't manage in time. These experiences are kept somehow inside us and without exposing them through therapy they tend to appear suddenly like an external or internal explosion. Visiting a Mental Health Specialist is an important step to our effective self management.

\section{Conclusion}

i. We are very selective on information about our mental health.

ii. We are sure about our diagnosis only after a Mental Health Professional names it.

iii. We soon take after our Psychological difficulties in order to deal with them effectively.

Your next submission with Juniper Publishers will reach you the below assets

- Quality Editorial service

- Swift Peer Review

- Reprints availability

- E-prints Service

- Manuscript Podcast for convenient understanding

- Global attainment for your research

- Manuscript accessibility in different formats ( Pdf, E-pub, Full Text, Audio)

- Unceasing customer service

Track the below URL for one-step submission https://juniperpublishers.com/online-submission.php 